\title{
ENDOPARASITE INFRACOMMUNITIES OF Hemisorubim platyrhynchos (VALENCIENNES, 1840) (PISCES: PIMELODIDAE) OF THE BAÍA RIVER, UPPER PARANÁ RIVER FLOODPLAIN, BRAZIL: SPECIFIC COMPOSITION AND ECOLOGICAL ASPECTS
}

\author{
GUIDELLI, G. M., ${ }^{1}$ ISAAC, A., ${ }^{1}$ TAKEMOTO, R. M. ${ }^{2}$ and PAVANELLI, G. C. ${ }^{3}$ \\ ${ }^{1}$ Universidade Estadual de Maringá (UEM), Departamento de Biologia (DBI), Programa de Pós-graduação em \\ Ecologia de Ambientes Aquáticos Continentais (PEA), Av. Colombo, 5790, Bloco G-90, \\ CEP 87020-900, Maringá, PR, Brazil \\ ${ }_{2}^{2}$ Pesquisador do Nupélia (Núcleo de Pesquisa em Limnologia, Ictiologia e Aqüicultura)/ \\ Pesquisador Científico do $\mathrm{CNPq}$ \\ ${ }^{3}$ DBI/UEM/PEA/Nupélia/Pesquisador Científico do CNPq, Nível 1 \\ Correspondence to: Gislaine M. Guidelli, Universidade Estadual de Maringá/Nupélia, Av. Colombo, 5790, Bloco \\ G-90, CEP 87020-900, Maringá, PR, Brazil, e-mail: gmguidelli@ nupelia.uem.br \\ Received September 4, 2002 - Accepted October 21, 2002 - Distributed May 31, 2003
}

\begin{abstract}
Parasites of 136 specimens of Hemisorubim platyrhynchos, popularly called jurupoca, were analyzed. Fourteen parasite species were recorded: four digeneans (Crocodilicola pseudostoma, one Gorgoderidae species, Sanguinicola platyrhynchi, and Sphincterodiplostomum sp.); three cestodes (Goezeella paranaensis, Spatulifer maringaensis, and Mariauxiella piscatorum); five nematodes (Contracaecum Type 1 larvae of Moravec, Kohn, \& Fernandes, 1993; Contracaecum Type 2 larvae of Moravec, Kohn, \& Fernandes, 1993; Cucullanus (Cucullanus) zungaro; Eustrongylides ignotus; and Goezia sp.); one acanthocephalan (Quadrigyrus machadoi), and one pentastomid (Sebekia sp.). Most of the helminth specimens were found in larval stages, confirming that $H$. platyrhynchos is a significant source of their transmission. No dominance was reported. With the exception of Contracaecum Type 2 (featuring random dispersion), the species had a clumped pattern of dispersion in the host sample. Evidence of competition among parasite species was not reported. Several species of parasites were correlated with host size and sex. This fact may be explained by increase in food content and possible behavioral modifications of male and female hosts. Infracommunity diversity was not related to host size or sex.
\end{abstract}

Key words: helminths, ecology, fishes, Hemisorubim platyrhynchos, Brazil.

\section{RESUMO}

Infracomunidades de endoparasitas de Hemisorubim platyrhynchos (Valenciennes, 1840) (Pisces: Pimelodidae) do rio Baía, planície de inundação do alto rio Paraná, Brasil: composição específica e aspectos ecológicos

Foram examinados os parasitas de 136 espécimes de Hemisorubim platyrhynchos, chamados popularmente de jurupoca. Quatorze espécies de parasitas foram registradas: quatro de digenéticos (Crocodilicola pseudostoma, uma espécie da família Gorgoderidae, Sanguinicola platyrhynchi e Sphincterodiplostomum sp.); três de cestóides (Goezeella paranaensis, Spatulifer maringaensis e Mariauxiella piscatorum); cinco de nematóides (Contracaecum Tipo 1 larva de Moravec, Kohn \& Fernandes, 1993; Contracaecum Tipo 2 larva de Moravec, Kohn \& Fernandes, 1993; Cucullanus (Cucullanus) zungaro; Eustrongylides ignotus; e Goezia sp.); uma de acantocéfalo (Quadrigyrus machadoi) e uma de pentastomídeo (Sebekia sp.). A maioria dos espécimes de helmintos estava em estágio larval de desenvolvimento, confirmando que $H$. platyrhynchos é uma importante fonte de transmissão para esses parasitas. Não houve dominância. As espécies mostraram padrão agregado 
de distribuição na amostra de hospedeiros, com exceção de Contracaecum Tipo 2, que apresentou distribuição casual. Não houve evidências de competição entre as espécies de parasitas. Várias espécies mostraramse correlacionadas com o tamanho e o sexo dos hospedeiros, o que pode ser originado por aumentos no volume de alimento ingerido e possíveis modificações comportamentais entre os sexos. Não houve correlação entre a diversidade das infracomunidades e o tamanho ou sexo dos hospedeiros.

Palavras-chave: helmintos, ecologia, peixes, Hemisorubim platyrhynchos, Brasil.

\section{INTRODUCTION}

Hemisorubim platyrhynchos (Valenciennes, 1840), popularly called jurupoca, is a pimelodid fish inhabiting large South American rivers (Burguess, 1989). According to Ringuelet et al. (1967), this species can be found in Brazil in the Amazon, Parnaíba, and Paraná rivers and their tributaries. It is considered an important species in the fisheries of the Paraná River basin (Agostinho et al., 1995). In spite of its importance in the region under analysis, the parasite fauna and parasite ecology of this host are still unknown. This paper aims to provide information on the endoparasite infracommunities of $H$. platyrhynchos of the Baía River (Upper Paraná River floodplain) and deals with aspects that may influence infracommunity structures in this locality.

\section{MATERIAL AND METHODS}

One hundred and thirty-six specimens of Hemisorubim platyrhynchos were caught between August 1998 and July 1999 in the Baía River (22 42'$22^{\circ} 44^{\prime} \mathrm{S}$ and $53^{\circ} 17^{\prime}-53^{\circ} 20^{\prime} \mathrm{W}$ ), State of Mato Grosso do Sul, Brazil. This river lies within a wide flood region in the upper section of the Paraná River (Maack, 1981). Fish captures were undertaken using gill nets. The total weight, standard length, and sex of each fish were registered. Internal organs and the visceral cavity were analyzed under a stereomicroscope. The collected parasites were treated according to Eiras et al. (2000) and identified based on Travassos et al. (1969), Yamaguti (1971), Pavanelli \& Rego (1989), Thatcher (1993), Moravec (1998), and Chambrier \& Vaucher (1999).

Data analyses were made using the following ecological indexes and statistical tests: Simpson's index (C) to determine dominance trends among parasite species, dominance being accepted when
C > 0.25 (Stone \& Pence, 1978); the Dispersion index, tested using "d" statistics in accordance with Ludwig \& Reynolds (1988), to verify the dispersion pattern of parasite species in sample hosts; Chi-square test to determine the occurrence of associations among species and Spearman's rank correlation (rs) to verify correlations between abundance of the species that formed associated (Ludwig \& Reynolds, 1988); Shannon's index (H') to determine infracommunity diversity, computed using PC-ORD software (MacCune \& Mefford, 1997); Pearson's linear correlation (r), with previous angular transformation of prevalence ( $\operatorname{arc}$ sen $\sqrt{\chi}$ ), calculated to determine the correlation between host standard length and parasite prevalence (Zar, 1996); Spearman's rank correlation (rs) to verify the correlation between standard length and parasite abundance and diversity (Zar, 1996); the "G" loglikelihood test (using the $2 \times 2$ contingency table) and Mann-Whitney's test (U), used to determine the effects of host sex in the prevalence and abundance of each species, respectively (Zar, 1996); and Student's t test, calculated to verify differences in the diversity of male and female host infracommunities (Zar, 1996). Statistical analyses were applied to parasite species with over $10 \%$ prevalence and the results considered significant when $\mathrm{p} \leq 0.05$. The ecological terms were suggested by Bush et al. (1997).

\section{RESULTS}

Specific composition of the endoparasite fauna All analyzed fishes were infected with one or more endohelminth species. Fourteen species were identified: four digeneans (Crocodilicola pseudostoma (Willemoes-Suhm, 1870) Poche, 1926; one species of the Gorgoderidae Looss, 1901; Sanguinicola platyrhynchi Guidelli, Isaac \& Pavanelli, 2002, and Sphincterodiplostomum sp.), three cestodes (Goezeella paranaensis Pavanelli \& Rego, 
1989; Spatulifer maringaensis Pavanelli \& Rego, 1989; and Mariauxiella piscatorum Chambrier \& Vaucher, 1999), five nematodes (Contracaecum Type 1 larvae of Moravec, Kohn, \& Fernandes, 1993 and Contracaecum Type 2 larvae of Moravec, Kohn, \& Fernandes, 1993); Cucullanus (Cucullanus) zungaro Vaz \& Pereira, 1934; Eustrongylides ignotus Jägerskiöld, 1909 and Goezia sp.), one acanthocephalan (Quadrigyrus machadoi Fábio, 1983), and one pentastomid (Sebekia sp.) (Table 1).

Progenetic metacercariae of C. pseudostoma were observed, which facilitated identification at the specific level. Gorgoderidae could not be identified at a lower taxon because of the small number of individuals collected.

\section{Ecological aspects of the endoparasite infracommunity}

Among the total number of helminth individuals collected, 48.3\% (1638) were adults and 51.6\% (1751) were larvae. C. pseudostoma, Sanguinicola platyrhynchi, G. paranaensis, Contracaecum Type 1, and Q. machadoi had the highest prevalence, mean intensity, and mean abundances (Table 1). Simpson's index did not indicate any dominance trend in the endoparasite infracommunities $(C=0.1273)$. Most parasite species presented a clumped pattern of dispersion in the host sample, as shown by the Dispersion index. Only Contracaecum Type 2 showed random dispersion (Table 2).

Among the 28 possible associations, the pairs G. paranaensis/S. maringaensis, $M$. piscatorum/S. maringaensis, and $G$. paranaensis/Sanguinicola platyrhynchi presented significant positive associations and significant positive correlation between abundances. Abundances were correlated positively in four other pairs of species ( $G$. paranaensis/M. piscatorum; $Q$. machadoi/S. maringaensis; Q. machadoil Contracaecum Type 1 ; and C. pseudostoma/Contracaecum Type 2) (Table 3).

Individual fishes harbored between 1 and 9 species. Among the total number of fishes, $69.92 \%$ harbored 4-6 parasite species whereas infracommunities with more than 6 species were rare $(15.03 \%)$. Infracommunities richness was as follows: 3 infracommunities had only 1 parasite species; 6 had 2; 11 had 3; 24 had 4; 33 had 5; 36 had 6; 14 had 7; 5 had 8 and 1 had 9 . Mean diversity amounted to 1.239 $(0-1.968, \mathrm{SD}=3.816)$, with most infracommunities recording diversity higher than mean.
Fish standard length varied from 18 to 41.4 centimeters. Significant positive correlations between host standard length and abundance of the three cestode species were observed (G. paranaensis: $\mathrm{rs}=$ $0.2490,0.005>\mathrm{p}>0.002 ;$ M. piscatorum: $\mathrm{rs}=0.2898$, $\mathrm{p}<0.001 ;$ S. maringaensis: $\mathrm{rs}=0.2260,0.01>\mathrm{p}>$ 0.005). G. paranaensis and Contracaecum Type 2 showed a significant positive correlation between prevalence and host standard length $(\mathrm{r}=0.8658,0.05>$ $\mathrm{p}>0.02 ; \mathrm{r}=0.9280,0.01>\mathrm{p}>0.005$, respectively). There was a significant negative correlation between host standard length and prevalence of Contracaecum Type $1(\mathrm{r}=-0.8825,0.02>\mathrm{p}>0.01)$. Correlations between host size and infracommunity diversity and richness were not observed ( $\mathrm{rs}=-0.018, \mathrm{p}>0.5$; rs $=0.0857,0.5>\mathrm{p}>0.2$, respectively).

Forty-one males and 87 females were studied. It was impossible to determine the sex of eight specimens. There was a significant relationship between host sex and prevalence of $G$. paranaensis and $M$. piscatorum $(\mathrm{G}=5.395,0.025>\mathrm{p}>0.01$; and $\mathrm{G}=8.587,0.005>\mathrm{p}>0.001$, respectively), with the females being more infected. A significant relationship between $M$. piscatorum abundance and host sex was observed $(Z=2.78,0.01>p>0.005)$, with the highest abundance also occurring in the females. Infracommunities in the female hosts had a mean diversity of $1.262(0-1.968)$ and a mean richness of 5.2 (1-9). In the male hosts these values were 1.188 (0-1.704) and 4.7 (1-7), respectively. However, Student's t test indicated that diversity and richness are independent of host sex $(t=0.983$, $\mathrm{p}=0.3272 ; \mathrm{t}=-1.7261, \mathrm{p}=0.0879$, respectively).

\section{DISCUSSION}

\section{Specific composition of the endoparasite fauna}

Host feeding habit and diet are important in helminth acquisition. According to Dogiel (1970), the habitat from which the main bulk of food is obtained is as important as the diet in parasite fauna composition. It is a well-known fact that the main food source for fish analyzed in the present paper is of autochthonous origin. Hemisorubim platyrhynchos is a piscivorous species that feeds on small foraging fishes (Hahn et al., 1997) which, according to Eiras (1994), were intermediate or paratenic hosts in the life cycle of parasites such as the digeneans, cestodes, and nematodes observed in this paper. 


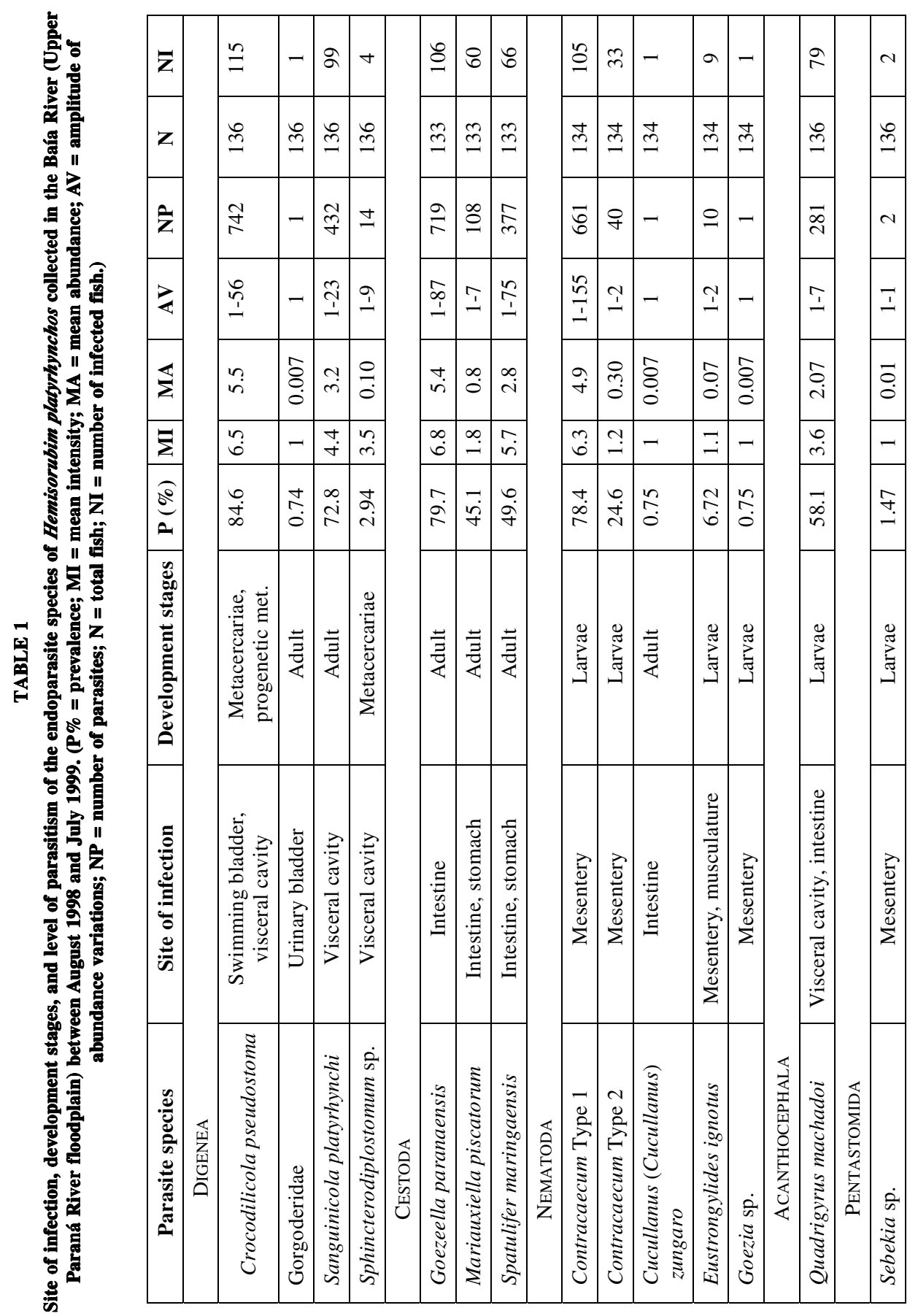


TABLE 2

Values of the Dispersion index and "d" statistics of the endoparasites of Hemisorubim platyrhynchos collected in the Baía River (Upper Paraná River floodplain) between August 1998 and July 1999. (d > 1.96 = clumped dispersion; $d<$ -1.96 = uniform dispersion; $d<1.96$ = random dispersion, according to Ludwig \& Reynolds (1988).)

\begin{tabular}{|l|c|c|c|}
\hline \multicolumn{1}{|c|}{ Parasite species } & ID & D & Dispersion type \\
\hline Crocodilicola pseudostoma & 15.12 & 47.14 & Clumped \\
\hline Sanguinicola platyrhynchi & 4.58 & 18.70 & Clumped \\
\hline Goezeella paranaensis & 20.40 & 56.94 & Clumped \\
\hline Spatulifer maringaensis & 23.26 & 61.91 & Clumped \\
\hline Mariauxiella piscatorum & 2.04 & 6.94 & Clumped \\
\hline Contracaecum Type 1 & 44.90 & 92.65 & Clumped \\
\hline Contracaecum Type 2 & 1.06 & 0.48 & Random \\
\hline Quadrigyrus machadoi & 5.18 & 20.92 & Clumped \\
\hline
\end{tabular}

TABLE 3

Associations of endoparasite species of Hemisorubim platyrhynchos collected in the Baía River (Upper Paraná River floodplain) between August 1998 and July 1999. $\left(\chi^{2}=\right.$ Chi-square for associations of pairs of species; rs = Spearman's rank correlation of species abundance of each pair; * significant.)

\begin{tabular}{|l|c|c|c|c|c|c|c|c|}
\hline \multicolumn{1}{|c|}{ Parasite species } & $\mathbf{1}$ & $\mathbf{2}$ & $\mathbf{3}$ & $\mathbf{4}$ & $\mathbf{5}$ & $\mathbf{6}$ & $\mathbf{7}$ & $\mathbf{8}$ \\
\hline $\begin{array}{l}\text { Crocodilicola } \\
\text { pseudostoma }(1)\end{array}$ & - & $\begin{array}{c}(+) \\
0.088\end{array}$ & $\begin{array}{c}(+) \\
0.280\end{array}$ & $\begin{array}{c}(-) \\
2.011\end{array}$ & $(+) 0.236$ & $\begin{array}{c}(-) \\
0.801\end{array}$ & $\begin{array}{c}(+) \\
2.603\end{array}$ & $\begin{array}{c}(+) \\
0.108\end{array}$ \\
\hline $\begin{array}{l}\text { Sanguinicola } \\
\text { platyrhynchi }(2)\end{array}$ & 0.027 & - & $\begin{array}{c}(+) \\
5.500^{*}\end{array}$ & $\begin{array}{c}(-) \\
0.062\end{array}$ & $(+) 0.000$ & $\begin{array}{c}(+) \\
1.727\end{array}$ & $\begin{array}{c}(+) \\
1.547\end{array}$ & $\begin{array}{c}(+) \\
0.157\end{array}$ \\
\hline $\begin{array}{l}\text { Goezeella } \\
\text { paranaensis (3) }\end{array}$ & 0.011 & $0.179^{*}$ & - & $\begin{array}{c}(+) \\
(+)\end{array}$ & $\begin{array}{c}(+) \\
(+)\end{array}$ & $\begin{array}{c}(+) \\
(+)\end{array}$ \\
\hline $\begin{array}{l}\text { Mariauxiella } \\
\text { piscatorum (4) }\end{array}$ & 0.124 & 0.027 & $0.278^{*}$ & - & $\begin{array}{c}(+) \\
4.400^{*}\end{array}$ & $\begin{array}{c}(-) \\
0.972\end{array}$ & $\begin{array}{c}(+) \\
0.352\end{array}$ & $\begin{array}{c}(-) \\
0.126\end{array}$ \\
\hline $\begin{array}{l}\text { Spatulifer } \\
\text { maringaensis (5) }\end{array}$ & 0.069 & 0.055 & $0.427 *$ & $0.322^{*}$ & - & $\begin{array}{c}(+) \\
0.000\end{array}$ & $\begin{array}{c}(+) \\
0.660\end{array}$ & $\begin{array}{c}(+) \\
2.525\end{array}$ \\
\hline $\begin{array}{l}\text { Contracaecum } \\
\text { Type 1 (6) }\end{array}$ & 0.052 & 0.015 & 0.081 & -0.021 & 0.048 & - & $\begin{array}{c}(+) \\
1.213\end{array}$ & $\begin{array}{c}(+) \\
3.594\end{array}$ \\
\hline $\begin{array}{l}\text { Contracaecum } \\
\text { Type 2 (7) }\end{array}$ & $0.179 *$ & 0.118 & 0.089 & 0.090 & 0.116 & 0.151 & - & $\begin{array}{c}(+) \\
0.924\end{array}$ \\
\hline $\begin{array}{l}\text { Quadrigyrus } \\
\text { machadoi (8) }\end{array}$ & -0.028 & 0.042 & 0.133 & 0.023 & $0.248^{*}$ & $0.213 *$ & 0.012 & - \\
\hline
\end{tabular}

Thus, host feeding habits were an important factor in determining the endoparasite fauna composition in these infracommunities. This composition comprised several species with high infection levels, much like other piscivorous species from the same region, such as Pseudoplatystoma corruscans (Agassiz, 1829) and Hoplias malabaricus (Bloch, 1794) (Machado et al., 1996; Almeida, 1998). The studied endoparasite infracommunities included autogenic and allogenic species, a fact explained by the position of the host in the food web. The fish is a great predator within the aquatic environment; however, it occupies an intermediate position in the food web, being preyed on by land animals. Thus, the host is highly important to the allogenic species (mainly the larvae with high prevalences such as $C$. pseudostoma, Contracaecum Type 1 , and Q. machadoi) in the completion of their life cycle. 
Progenetic metacercariae of C. pseudostoma were observed in the jurupoca endoparasite infracommunities. Pérez-Ponce de Leon et al. (1992) also reported the occurrence of the progenetic metacercariae of this species in Rhamdia guatemalensis, another pimelodid fish from Mexico. According to Zdzitowiecki (1997), progenetic metacercariae can mature and produce eggs in intermediate hosts. This was observed in some specimens of $C$. pseudostoma parasitizing jurupocas.

\section{Ecological aspects of the endoparasite infracommunity}

The high abundance of larvae observed in this study suggests a cumulative effect in helminth infection during this stage. Larvae of previous and more recent infections could be found side by side in the same host individual. Santos \& Eiras (1995) have also suggested a cumulative effect in larval infection by digenean Lecithochirium furcolabiatum Jones, 1933 from Portugal. Espinosa-Huerta et al. (1996) mentions the same by digenean Posthodiplostomum minimum (MacCallum, 1921) Dubois, 1936 in fishes from Mexico.

Clumped distribution is considered typical in parasites of freshwater fishes and has also been reported in other fish species in the region (Almeida, 1998; Brasil-Sato, 1999; Machado et al., 2000). Individual differences in immunological reaction and susceptibility to infection might have caused the clumped pattern. This dispersion pattern may be increasing reproductive efficiency in some adult species (e.g., cestodes), since it enhances mating opportunities (Holmes, 1990). However, according to this author, such local aggregations may be widely dispersed throughout the intestine. In this case, additional studies on intestinal distribution are suggested.

According to Dobson (1990), clumped distribution tends to magnify the stability of the hostparasite relationship, since regulating mechanisms of parasite populations (such as host mortality, reductions in parasite fecundity, and density-dependent survival) influence a greater proportion of these populations. Only Contracaecum Type 2 showed random dispersion. Its possibly reduced opportunity to colonize the host, as well as pathological effects, must have contributed towards its random dispersion. According Dobson (1990), rare or more pathogenic species are frequently less aggregated. In addition, according to Moravec (1998), some Contracaecum larvae may have pathogenic effects.
Positive associations among cestode species G. paranaensis/S. maringaensis and M. piscatorum/ $S$. maringaensis, with positive abundance correlations, may demonstrate that they have the same ecological requirements, which must be abundantly available. For example, cestodes have common microhabitats and are known to absorb monosaccharides (sometimes disaccharides) (Holmes, 1990). It is thus probable that food and space are abundant, while the occurrence of competition or other interference mechanisms suggested by Holmes (1990) is less probable. These cestode species may use the same or similar intermediate hosts, which are a frequent item in the fish diet. This fact may explain why none of the cestodes dominated the infracommunities separately. The positive association and correlation shown by G. paranaensis/S. platyrhynchi must be related to infection strategies and not to the direct interactions of these species, since they have different microhabitats. This conclusion agrees with Dobson (1990), i.e., the abundance and distribution of parasites are more a direct result of different life cycle characteristics than of interactions among species (e.g., competition).

Although infracommunities can present great richness (14 species of helminths were found in the host species), they had a maximum of 9 species. Though a species of fish presents high parasite richness, if the opportunities of transmission are low for some representatives, the probability of occurring together in a single fish is very low. According to Kennedy (1990), the number of species in an infracommunity reflects the number of species in the locality, the opportunity of transmission and infection, and, thus, the probability of host infection. Differences in species richness and diversity of the infracommunities may also be the result of individual responses to parasitism by different species of helminths and transmission rates. Interspecific competition may also play an important role in parasite richness, although no evidence of competition has been obtained.

Studies that relate parasitism with host size may indicate how parasite infracommunities structure changes during the life cycle of the host. Community organization may be influenced by host age and size through changes in diet or the volume of ingested food, ontogenetic changes in immunocompetency, and modifications in the probability of contact with intermediate hosts (Esch et al., 1990). 
Increase in endoparasite abundance in larger fishes, as verified in this study for the three cestode species, has been attributed by Isaac et al. (2000) to the occurrence of cumulative processes in the infection. Although accumulation of parasites may occur, other processes are also involved. Feeding habit changes or use of intermediate hosts whose ingestion is limited by fish size may cause this infection pattern. However, no records exist of changes in the feeding habit or diet of jurupocas in the analyzed size classes. Moreover, no correlation was verified between prevalence and host size in the case of $M$. piscatorum and $S$. maringaensis. Although a positive correlation was observed for $G$. paranaensis, some small-sized specimens were infected. Thus, the abundance increase in larger fishes might be related to an increase in ingested food volume, as observed by Zelmer \& Arai (1998) in yellow perch parasitized by Crepidostomum isostomum and Raphidascaris acus (Bloch, 1770). One may conclude that infection is probably not dependent on host size but the rates in which it occurs do. Although there was an increase in abundance in larger fishes, smaller fishes were also infected. Takemoto \& Pavanelli (1994), Machado et al. (1994), and Takemoto \& Pavanelli (2000) have also observed cestode infection increases in larger pimelodid fishes on the Upper Paraná River floodplain.

Contracaecum Type 1 showed negative correlation between fish size and prevalence whereas Contracaecum Type 2 had a positive correlation. This fact suggests the possibility of different transmission strategies and the use of different intermediate hosts by these congeneric species. The acquired immunity might justify the lower infection rate of $C$. Type 1 among the larger fishes.

Changes in behavior or habits due to an increase in host size might influence infracommunity diversity (Esch et al., 1990). However, in the present paper, possible changes in the volume of food ingested by $H$. platyrhynchos were not responsible for changes in endoparasite diversity among infracommunities in fishes of different sizes.

The prevalence of $G$. paranaensis and $M$. piscatorum and the abundance of the latter were dependent on host sex, and female hosts were more parasitized. These results differ from those of Takemoto \& Pavanelli (2000), who observed that the cestode species of Sorubim lima, also a pimelodid fish, were more numerous in male hosts. Differences in the infection of the male and female hosts in the present study may be due to their different behaviors and, consequently, to differences in exposure to infection. However, additional investigations are necessary at the biochemical level, since Zaman \& Seng (1989) and Folstad \& Karter (1992) cited by Poulin (1996) mentioned the influence of sexual hormones on infection.

Segregation of infections by $C$. Type 1 in smaller fishes and by cestodes in female and larger fishes may have contributed to the clumped pattern of these species. Zelmer \& Arai (1998) reported the contribution of host size to parasite aggregation in the yellow perch from Canada. Other factors without any relationship to fish sex or size must be involved in the aggregation of species. Life cycle features of each parasite species or the differentiated immunological response among host individuals may have produced this pattern.

Acknowledgments - We would like to thank Nupélia (Nucleus for Research in Limnology, Ichthyology, and Aquaculture) for the use of their facilities in carrying out this research, CAPES for a Fellowship, and the coordinators of the Graduate Course in Ecology of Continental Aquatic Environments, State University of Maringá, for their support during every stage of this work.

\section{REFERENCES}

AGOSTINHO, A. A., VAZZOLER, A. E. A. M. \& THOMAZ, S. M., 1995, The high Paraná river basin: limnological and ichthyological aspects. In: J. G. Tundisi, C. E. M. Bicudo \& T. Matsumura-Tundisi (eds.), Limnology in Brazil. Brazilian Academy of Sciences, Brazilian Limnological Society, Rio de Janeiro, pp. 59-103.

ALMEIDA, S. C., 1998, Aspectos ecológicos dos endohelmintos parasitos de Hoplias malabaricus (Bloch, 1794) (Ostheichthyes - Erythrinidae) do alto rio Paraná, região de Porto Rico, Paraná, Brasil. Dissertação de Mestrado, Universidade Estadual de Maringá, Maringá, 50p.

BRASIL-SATO, M. C., 1999, Ecologia das comunidades de parasitos metazoários de Pimelodus maculatus Lacépède, 1803 (Siluriformes: Pimelodidae) das bacias do rio São Francisco, Três Marias, MG, e do rio Paraná, Porto Rico, $P R$. Tese de Doutorado, Universidade Federal de São Carlos, São Carlos, 255p.

BURGESS, W. E., 1989, An atlas of freshwater and marine catfishes: a preliminary survey of the Siluriformes. T.F.H. Publications, New Jersey, 784p.

BUSH, A. O., LAFFERTY, K. D., LOTZ, J. M. \& SHOSTAK, A. W., 1997, Parasitology meets ecology on its own terms: Margolis et al. revisited. J. Parasitol., 83(4): 575-583.

CHAMBRIER, A. \& VAUCHER, C., 1999, Proteocephalidae et Monticelliidae (Eucestoda: Proteocephalidea) parasites de poissons d'eau douce au Paraguay, avec descriptions d'un genre nouveau et de dix espèces nouvelles. Rev. Suisse Zool., 106(1): 165-240 
DOBSON, A. P., 1990, Models of multi-species parasites-host communities. In: G. W. Esch, A. O. Bush \& J. Aho (eds.), Parasite communities: patterns and process. Chapman and Hall, New York, pp. 261-287.

DOGIEL, V. A., 1970, Ecology of the parasites of freshwater fishes In: V. A. Dogiel, G. K. Petrushevski \& Y. I. Polyansky (eds.), Parasitology of fishes. Olivier \& Boyd, London, pp. 1-47.

EIRAS, J. C., 1994, Elementos de ictioparasitologia. Fundação Eng. António de Almeida, Porto, 339p.

EIRAS, J. C., TAKEMOTO, R. M. \& PAVANELLI, G. C., 2000 Métodos de estudo e técnicas laboratoriais em parasitologia de peixes. EDUEM, Maringá, 171p.

ESCH, G. W., SHOSTAK, A. W., MARCOGLIESE, D. J. \& GOATER, T. M., 1990, Patterns and processes in helminth parasite communities: an overview. In: G. W. Esch, A. O. Bush \& J. Aho (eds.), Parasite communities: patterns and process. Chapman and Hall, New York, pp. 1-19.

ESPINOSA-HUERTA, E., GARCÍA-PRIETO, L. \& PÉREZPONCE de LEÓN, G., 1996, Helminth community structure of Chirostoma attenuatum (Osteichthyes: Atherinidae) in two Mexican lakes. South. Nat., 41(3): 288-292.

HAHN, N. S., ANDRIAN, I. F., FUGI, R. \& ALMEIDA, V. L. 1997, Ecologia trófica. In: A. E. A. M. Vazzoler, A. A. Agostinho \& N. S. Hahn (eds.), A planície de inundação do alto rio Paraná: aspectos físicos, biológicos $e$ socioeconômicos. EDUEM, Maringá, pp. 209-228.

HOLMES, J. C., 1990, Competition, contacts, and other factors restricting niches of parasitic helminths. Ann. Parasitol. Hum. Comp., 65: 69-72.

ISAAC, A., GUIDELLI, G. M., TAKEMOTO, R. M. \& PAVANELLI, G. C., 2000, Prosthenhystera obesa (Digenea), parasite of Salminus maxillosus (Characidae) of the floodplain of the upper Paraná River, Paraná Brazil: influence of the size and sex of host. Acta Scientiarum, 22(2): 523-526.

KENNEDY, C. R., 1990, Helminth communities in freshwater fish: structured communities or stochastic assemblages? In: G. W. Esch, A. O. Bush \& J. Aho (eds.), Parasite communities: patterns and process. Chapman and Hall, New York, pp. 131-156

LUDWIG, J. A. \& REYNOLDS, J. F., 1988, Statistical ecology: a primer on methods and computing. Wiley-Interscience Publications, New York, 337p

MAACK, R., 1981, Geografia física do Estado do Paraná. $2^{\text {th }}$ ed., Livraria José Olympio Editora, Rio de Janeiro, 450p.

MacCUNE, B. \& MEFFORD, M. J., 1997, PC-ORD multivariate analysis of ecological data. Version 3.0. MjM Software design, Gleneden Beach, Oregon.

MACHADO, M. H., PAVANELLI, G. C. \& TAKEMOTO, R. M. 1994, Influence of host's sex and size on endoparasitic infrapopulations of Pseudoplatystoma corruscans and Schizodon borelli (Osteichthyes) of the high Paraná River, Brazil. Rev. Bras. Parasitol. Vet., 3(2): 143-148.

MACHADO, M. H., PAVANELLI, G. C. \& TAKEMOTO, R. M., 1996, Structure and diversity of endoparasitic infracommunities and the trophic level of Pseudoplatystoma corruscans and Schizodon borelli (Ostheichthyes) of the high Paraná River. Mem. Inst. Oswaldo Cruz, 91(4): 441-448.
MACHADO, P. M., ALMEIDA, S. C., PAVANELLI, G. C. \& TAKEMOTO, R. M., 2000, Ecological aspects of endohelminths parasitizing Cichla monoculus Spix, 1831 (Perciformes: Cichlidae) in the Paraná River near Porto Rico, State of Paraná, Brazil. Comp. Parasitol., 67(2): 210-217.

MORAVEC, F., 1998, Nematodes of freshwater fishes of the neotropical region. Academia, Praha, 464p.

PAVANELLI, G. C. \& REGO, A. A., 1989, Novas espécies de proteocefalídeos (Cestoda) de Hemisorubim platyrhynchos (Pisces: Pimelodidae) do Estado do Paraná. Rev. Brasil. Biol., 49(2): 381-386.

PÉREZ-PONCE DE LEÓN, G., OSORIO-SARABIA, D. \& GARCÍA-PRIETO, L., 1992, Helmintofauna del "juile" Rhamdia guatemalensis (Pisces: Pimelodidae), del lago de Catemaco, Veracruz. Rev. Soc. Mex. Hist. Nat., 43: 25-31.

POULIN, R., 1996, Sexual inequalities in helminth infections: a cost of being a male? Am. Nat., 147(2): 287-295.

RINGUELET, R. A., ARAMBURU, R. A. \& ARAMBURU, A. A., 1967, Los peces argentinos de agua dulce. Comisión de Investigación Científica, Buenos Aires, 602p.

SANTOS, M. J. \& EIRAS, J. C., 1995, A seasonal study on the parasitization of Lipophrys pholis (Pisces: Bleniidae) by Helicometra fasciata (Digenea: Opecoelidae) and Lecithochirium furcolabiatum (Digenea: Hemiuridae) in Portugal. Aquaculture, 132: 175-181.

STONE, J. E. \& PENCE, D. B., 1978, Ecology of helminth parasitism in the bobcat from West Texas. J. Parasitol., 64(2):295-302

TAKEMOTO, R. M. \& PAVANELLI, G. C., 1994, Ecological aspects of proteocephalidean cestodes parasites of Paulicea luetkeni (Steindachner) (Osteichthyes: Pimelodidae) from the Paraná River, Paraná, Brazil. Rev. UNIMAR, 16(Supl. 3): 17-26.

TAKEMOTO, R. M. \& PAVANELLI, G. C., 2000, Aspects of the ecology of proteocephalid cestodes parasites of Sorubim lima (Pimelodidae) of the upper Paraná River, Brazil: I. Structure and influence of host's size and sex. Rev. Brasil. Biol., 60(4): 577-584.

THATCHER, V. E., 1993, Trematódeos neotropicais. Instituto Nacional de Pesquisas da Amazônia, Manaus, Brasil, 553p.

TRAVASSOS, L., FREITAS, J. F. \& KOHN, A., 1969, Trematódeos do Brasil. Mem. Inst. Oswaldo Cruz, 67: 1-886.

YAMAGUTI, S., 1971, Synopsis of digenetic trematodes of vertebrates. Keigaku Publishing Co., Tokio, v. 1, 1074p.

ZAMAN, Z. \& SENG, L. T., 1989, The seasonal abundance of the parasite in Clarias batrachus and C. macrocephalus from two areas (Kedah and Perak) of Malaysia and its relationship to the maturity of the hosts. Bangladesh J. Zool., 17(1): 47-55.

ZAR, J. H., 1996, Biostatistical analysis. Prentice Hall, Inc. $3^{\text {rd }}$ ed., New Jersey, 662p.

ZDZITOWIECKI, K., 1997, Synopses of the Antarctic benthos. In: J. W. Wägele \& J. Sieg (eds.), Antarctic Digenea parasites of fishes. Koeltz Scientific Books, Koenigstein, pp. 9-22.

ZELMER, D. A. \& ARAI, H. P., 1998, The contributions of host age and size to the aggregated distribution of parasites in yellow perch, Perca flavecens, from Garner Lake, Alberta, Canada. J. Parasitol., 84(1): 24-28. 